Çukurova Üniversitesi Mühendislik Mimarlık Fakültesi Dergisi, 30(2), 267-273 ss., Aralık 2015

Çukurova University Journal of the Faculty of Engineering and Architecture, 30(2),pp. 267-273, December 2015

\title{
İş Güvenliği Risk Değerlendirme Analiz Modellemesi ve Yazılımının Bulanık Mantıkla Oluşturulması
}

\author{
Mehmet ZILE ${ }^{* 1}$ \\ ${ }^{1}$ Mersin Üniversitesi, UTIYO Bilişim Sistemleri Bölümü, Mersin
}

Özet

Geliş tarihi: 10.11. 2015

Kabul tarihi: 28.12.2015

İş sağlığı ve güvenliği genel olarak işyerlerindeki yapılan işlerle ilgili çalışan kişilerin vücut sağlıklarının ve can güvenliklerinin tam olarak sağlanması anlamına gelir. Ülkemizde, iş sağlı̆̆ı ve güvenliğindeki risk değerlendirme analizleri ahlaki, hukuki ve indirekt maliyetler açısından çok önemli bir hale gelmiştir. İşyerinde bulunan veya dışarıdan gelebilecek tehlikelerin tanımlanması, bu tehlikelerin riske dönüşmesine yol açan faktörler ile tehlikelerden kaynaklanan risklerin analiz edilerek derecelendirilmesi ve kontrol tedbirlerinin kararlaştırılması amacıyla yapılması gerekli çalışmalara risk değerlendirme ve analizi adı verilir. İş yerlerindeki riskler yapılan işlerden, yürütülen işlemler ve çeşitli yöntemlerden, kullanılan maddelerden, her türlü makine ve donanımlardan, iş yeri veya çevresinde bulunan çalışanlardan, iş yerinde oluşturulan organizasyonlardan çevre koşullarından ve çeşitli unsurların birbirleri ile etkileşmesinden kaynaklanır. Birçok belirli ve belirsiz tehlikeler olan işyeri ortamında risk değerlendirmesini ve bu tehlikeleri simule etmek için bir sistem modellemesi yapmak çok zordur. Bu çalışmada iş sağlığ 1 ve güvenliğinde bir çok tehlikeyi göz önüne alarak bulanık mantık temelli bir risk değerlendirme analiz modeli oluşturularak bir bilgisayar yazılımı geliştirilmiştir.

Anahtar Kelimeler: Risk değerlendirme, Analiz modellemesi, Bulanık mantık

\section{Establishment of Fuzzy Logic Safety Risk Assessment Modeling and Analysis Software}

\begin{abstract}
Occupational health and safety in the workplace in general about the work done by people working in the health of body and safety means ensuring the full. In our country, health and moral risk assessment analysis of the security, legal, and it has become very important in terms of indirect costs. The identification of hazards in the workplace or may come from outside, by analyzing the risks arising from the dangers and factors that led to the conversion of the risks of these hazards grading and control measures risk to be done for the purpose of deciding the necessary work of assessment and analysis is called. The work carried out risks in the work place, the actions carried out and the various methods used substances, all kinds of machines and the equipment, workplace or around which the employees, the environment of the organization that was created in the workplace and are caused by interactions with each of the various elements. Many specific risk assessment of the workplace environment and the uncertain dangers and make a system modeling to simulate these hazards is very difficult. In this study, occupational health and safety, taking into account the danger of creating a model based on a risk assessment analysis software was developed a fuzzy logic.
\end{abstract}

Keywords: Risk analysis, Analysis modeling, Fuzzy logic

\footnotetext{
*Yazışmaların yapılacağı yazar: Mehmet ZİLE, Mersin Üniversitesi, UTiYO Bilişsim Sistemleri Bölümü, Mersin, mehmetzile@mersin.edu.tr
} 


\section{GIIRIŞ}

Sanayileşmenin getirdiği tehlikeler, gelişmekte olan ülkelerde iș kazalarını artırmıștır. Kırsal kesimden kente hızlı göçler, eğitim seviyesi düşük çalışanların yapılan işlere uygunlaştırılamaması, olumsuz koşullarda çalışma ve yetersiz iş denetimleri, iş kazalarının artmasına neden olmuştur. Artan iş kazaları ve meslek hastalıkların önlenmesi ilk aşamada gerçeğe yakın doğruluk derecesi üst seviyede iyi bir risk değerlendirme analizi yapmakla mümkündür.

Bir kurumda iş sağlığı ve güvenliği ile ilgili tehlikelerin belirlenmesi, kimlerin nasil zarar görebileceğine karar verilmesi, risklerin analiz edilmesi, alınacak önlemlere karar verilmesi, bu önlemlerin uygulanması ile tehlikeler, riskler ve önlemlerin sürekli izlenerek gerekliyse değiştirilmesini ve daha fazla önlem almanın gerekip gerekmediğini içine alan bir süreçler bütününe Risk Değerlendirme Analizi adı verilir $[1,6,7]$.

Risk değerlendirmesi, mümkünse daha hiç kimse yaralanmadan ya da hastalanmadan sağlığa gelen olumsuzlukların nasıl, nerede, ne şekilde ortaya çıkabileceğini önceden öngörmeyi ve bu öngörüler doğrultusunda önlemleri en başından almayı amaçlar. İş yerlerindeki riskler yapılan işlerden, yürütülen işlemler ve çeşitli yöntemlerden, kullanılan maddelerden, her türlü makine ve donanımlardan, iş yeri veya çevresinde bulunan çalışanlardan, iş yerinde oluşturulan organizasyonlardan çevre koşullarından ve çeşitli unsurların birbirleri ile etkileşmesinden kaynaklanır [2,8].

Birçok belirli ve belirsiz tehlikeler olan işyeri ortamında risk değerlendirmesini ve bu tehlikeleri simule etmek için bir sistem modellemesi yapmak çok zordur.

$\mathrm{Bu}$ çalışmada iş sağlığı ve güvenliğinde bir çok tehlikeyi göz önüne alarak bulanık mantık temelli bir risk değerlendirme analiz modeli oluşturularak bir bilgisayar yazılımı geliştirilmiştir.

\section{BULANIK MANTIK KAVRAMI ve IŞ GÜVENLİĞí RISK DEĞERLENDİRME ve ANALIZINE UYGULANMASI}

\subsection{Bulanık Mantık Kavramı}

Bulanık mantık, bulanık eseme ya da puslu mantık, 1961 yılında Lütfü Aliasker Zade'nin yayınladığı bir makalenin sonucu oluşmuş bir mantık yapısıdır. Bulanık mantığın temeli bulanık küme ve alt kümelere dayanır. Klasik yaklaşımda bir varlık ya kümenin elemanıdır ya da değildir. Matematiksel olarak ifade edildiğinde varlık küme ile olan üyelik ilişkisi bakımından kümenin elemanı olduğunda “' 1 ”, kümenin elemanı olmadığ1 zaman "0" değerini alır. Bulanık mantık klasik küme gösteriminin genişletilmesidir [3]. Bulanık varlık kümesinde her bir varlığın üyelik derecesi vardır. Varlıkların üyelik derecesi, $(0,1)$ aralığında herhangi bir değer olabilir ve üyelik fonksiyonu M(x) ile gösterilir. Şekil 1'de görüldüğü gibi, örnek olarak normal oda sıcaklığını 23 derece olarak kabul edersek klasik küme kuramına göre 23 derecenin üzerindeki sicaklık derecelerini sicak olarak kabul ederiz ve bu derecelerin sicak kümesindeki üyelik dereceleri " 1 ” olur.

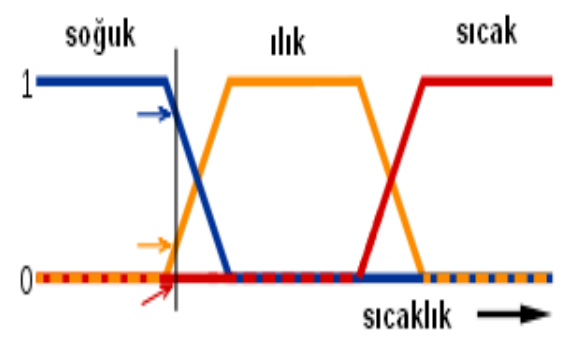

Şekil 1. Bulanık mantık

23 altındaki sıcaklık dereceleri ise soğuktur ve sıcak kümesindeki üyelik dereceleri " 0 " olur. Soğuk kümesini temel aldığımızda bu değerler tersine döner. Bulanık küme yaklaşımında üyelik değerleri $(0,1)$ aralığında değerler almaktadır. Örneğin 14 derecelik sıcaklık için üyelik derecesi " 0 ", 23 sicaklık derecesi için üyelik değeri " 0,25 " olabilir. Klasik kümelerin aksine bulanık 
kümelerde elemanların üyelik dereceleri $(0,1)$ aralığında sonsuz sayıda değişebilir. Bunlar üyeliğin derecelerinin devamlı ve aralıksız bütünüyle bir kümedir. Keskin kümelerdeki soğuk-

sıcak, hızlı-yavaş, aydınlık-karanlık gibi ikili değişkenler, bulanık mantıkta biraz soğuk, biraz sıcak, biraz karanlık gibi esnek niteleyicilerle yumuşatılarak gerçek dünyaya benzetilir [4].

Tanımlama 1. Bulanık Küme; $x=\{x\}$ olsun x ile belirtilen elemanların olduğu klasik bir kümeyi ifade etsin. O zaman, $\mathrm{x}$ deki bulanık küme, A düzenlenmiş çiftlerin kümesini gösterir.

$$
A=\left\{\left(x, \mu_{A}(x)\right), x \in X\right\}
$$

$\mu_{\mathrm{a}}$, A'daki x in üyelik derecesi olarak düşünülür. 0 ve 1 değerleri arasında değer alır. 0 ile en düşük, 1 ile en yüksek üyelik dereceyi belirtir. $\mu_{\mathrm{A}(\mathrm{x})}=0$ olduğunda $\mathrm{x}$ in $\mathrm{A}$ ya ait olmadığını ve $\mu_{\mathrm{A}(\mathrm{x})}=1$ olduğunda ise $\mathrm{x}$ in A ya ait olduğu ifade edilir.

Tanımlama 2. İki Bulanık Kümesinin Bileşimi; İki fuzzy kümesinin bileşimi A ve B (AUB), A'da veya $B$ 'de veya her ikisinde bütün elemanları kapsayan en küçük bulanıklık kümesidir. Buradan bileşme mantıksal OR oparatörü ile ifade edilir. AUB nin üyelik fonksiyonları aşağıda verilmiştir. Eğer $a \geq b$ ise $\max (a, b)=a$ ve eğer $a<b$ ise max $(\mathrm{a}, \mathrm{b})=\mathrm{b}$ olduğunda

$\mu_{\mathrm{AUB}(\mathrm{x})}=\max \left(\mu_{\mathrm{A}(\mathrm{x})}, \mu_{\mathrm{B}(\mathrm{x})}\right), \mathrm{x} \in \mathrm{X}$ dir.

Tanımlama 3. İki Bulanık Kümesinin Kesişmesi; $A$ ve B (AUB) nin kesişmesi A, B ve her ikisi içerisinde en geniş bulanık kümesidir. Kesişme mantıksal AND işlemcisi ile ifade edilir. Eğer $a \leq b$ ise $\min (a, b)=a$ ve eğer $a>b$ ise $\min (a, b)=b$ olduğunda AUB nin üyelik fonksiyonu şu şekildedir.

$\mu_{\mathrm{AUB}(\mathrm{x})}=\min \left(\mu_{\mathrm{A}(\mathrm{x})}, \mu_{\mathrm{B}(\mathrm{x})}\right), \quad \mathrm{x} \in \mathrm{X}$

Bir kez bulanık değişkenler tanımlanır ve üyelik fonksiyonları onlara atanır. Bulanık kümelerinin tanımlanmasında başvurulan bazı kurallar vardır. İlki, her bir değişkeni atanan bulanık kümesinin sayısı genellikle tek bir sayıdır. Bu, yan yana değerler arasında nümerik salınımı önlemek için bir merkez noktasının varlığını sağlar. İkinci olarak, bulanık kümesinin sayısı genellikle 3 ve 9 arasındadır. Nedensel ilişkileri tanımlamak için, dilsel değişkenlerin kullanımıyla, diğerinden bir alt kümeyi ayırt edebilmemiz gerekir. Alt kümelerin sayısının büyük olması bunu daha da zorlaştırır. Kısa, orta ve uzun değişken değerlerini ayırt etmek kolaydır. Fakat bir çok dereceli veri olmasıyla bu durum zorlaşır. Alt kümelerin dilsel tanımlamalarına yorum getirilebilir. Aynı zamanda her bir bulanık kümesi bileşik kümeleri üst üste getirmelidir. $\mathrm{Bu}$ üst üste getirme, bulanık denetleyici için sürekli kontrol alanını sağlar. Bileşik kümeler arasında, genellikle \%10-50 üst üste gelmesi istenir. Bulanıklık kümeleri tanımlandıktan ve onların üyelik fonksiyonlarını atadıktan sonra, kurallar kontrol değişkeninin her bir kombinasyonu için yazılmalıdır. Bu kurallar, karar vermede If-Then ifadelerini kullanarak, giriş değişkenleriyle çıkış değişkenleri arasında ilişki kurulacaktır. If şartı her bir kuralın Then sonucuna giden bir önertidir. Genelde her bir kural If (önerti) Then (sonuç) tarzında gösterilir.

\subsection{Risk Değerlendirme ve Analizi}

İşyerinde var olan ya da dışarıdan gelebilecek tehlikelerin belirlenmesi, tehlikelerden kaynaklanan risklerin derecelendirilmesi, kontrol tedbirlerinin kararlaştırılması, uygulanması ve uygulamalarının izlenmesi amacıyla yapılması gerekli çalışmalara Risk Değerlendirme ve Analizi olarak tanımlanır [4,5]. Şekil 2'de Risk Değerlendirme ve Analizinin nasıl yapılacağı gösterilmiştir.

\subsection{Bulanık Mantığın İş Güvenliği Risk Değerlendirmesine Uygulanması}

İşyerinde insana zarar verebilecek; t: tehlike (1 den tehlike sayısı $\mathrm{T}$ ye kadar), d: değer, $\mathrm{d}_{\mathrm{t}}{ }^{\max }$ :tehlikenin maksimun değeri, $\mathrm{Nd}$ : tehlikesiz değer (üyelik derecesi $\ddot{u}_{\text {ŞiDDET }}=0$ ), dd: çok düşük tehlikeli değer (üyelik derecesi üșiDDET=0,2), Dd: düşük tehlikeli değer (üyelik derecesi üsiDDET $=0,4$ ), Od: orta tehlikeli değer (üyelik derecesi üșiDDET $=0,6$ ), yd:yüksek tehlikeli değer (üyelik derecesi üşiDDET $=0,8), \quad Y d$ : çok yüksek tehlikeli değer (üyelik derecesi üșiDDET $=1,0$ ) olarak gösterilir. 


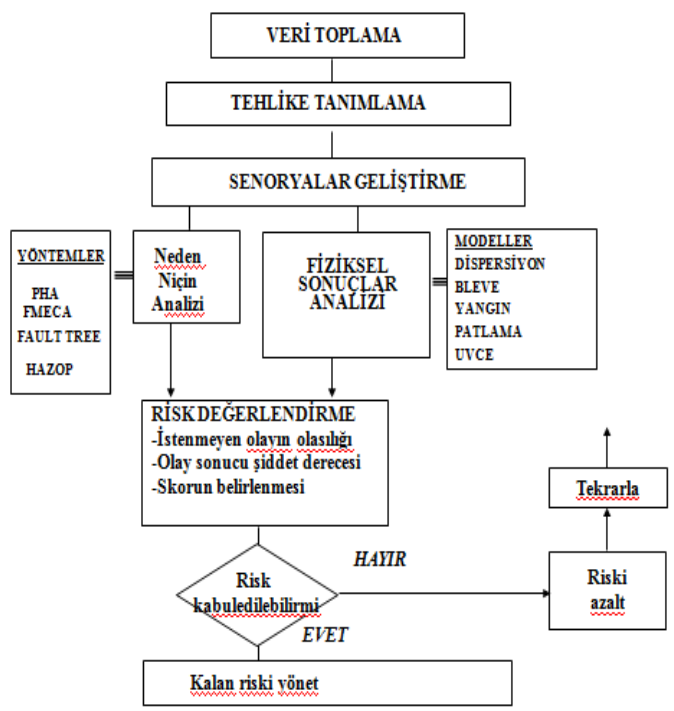

Şekil 2. Risk Değerlendirme ve Analizi

İş yeri ortamı olarak; $t$ (1) : işyeri ortam 1 sIS1 $\left(15^{\circ} \mathrm{C}\right.$ altına indiğinde ve $25^{\circ} \mathrm{C}$ üstüne çıktı̆̆ında $)$ $\mathrm{d}_{1}{ }^{\min }=10^{\circ} \mathrm{C}$ ve $\mathrm{d}_{1}{ }^{\max }=35^{\circ} \mathrm{C}$

$\mathrm{t}(2)$ : hava akım hızı $(0,5 \mathrm{~m} / \mathrm{sn}$ nin altına indiğinde ve $1 \mathrm{~m} / \mathrm{sn}$ nin üstüne çıktığında)

$\mathrm{d}_{2}{ }^{\min }=0,4 \mathrm{~m} / \mathrm{sn} \mathrm{ve}_{2}{ }^{\max }=1,1 \mathrm{~m} / \mathrm{sn}$

t (3) : bağıll nem (\%60'ın üzerine çıktı̆̆ında) $\mathrm{d}_{3}{ }^{\max }=\% 60$

İş yeri ortamında boğucu gaz olarak; t (4) : karbon monoksit, $\mathrm{d}_{4}{ }^{\max }=50 \mathrm{ppm}$,

t (5) : hidrojen siyanür, $d_{5}{ }^{\max }=10 \mathrm{ppm}, \mathrm{t}(6)$ : hidrojen siyanür, $\mathrm{d}_{6}{ }^{\max }=10 \mathrm{ppm}$

İş yeri ortamında zararlı metaller olarak; t (7) : kurşun, $\mathrm{d}_{7}{ }^{\max }=0,15 \mathrm{mg} / \mathrm{m}^{3}$

$\mathrm{t}(8)$ : civa, $\mathrm{d}_{8}{ }^{\max }=0,075 \mathrm{mg} / \mathrm{m}^{3}, \mathrm{t}(9)$ : arsenik, $\mathrm{d}_{9}{ }^{\mathrm{max}}=0,5 \mathrm{mg} / \mathrm{m}^{3}$

$\mathrm{t}(10)$ : kükürtlü hidrojen, $\mathrm{d}_{10}{ }^{\max }=20 \mathrm{ppm}, \mathrm{t}(11)$ : berilyum, $d_{11}{ }^{\max }=2 \mathrm{mg} / \mathrm{m}^{3}$

İş yeri ortamında tahriş edici gaz olarak olarak; $\mathrm{t}$ (12): amonyak, $\mathrm{d}_{12}{ }^{\max }=25 \mathrm{ppm}$

t (13) : klor, $\mathrm{d}_{13}{ }^{\max }=1 \mathrm{ppm}, \mathrm{t}$ (14) : azot dioksit, $\mathrm{d}_{14}{ }^{\max }=5 \mathrm{ppm}$

$\mathrm{t}(15)$ : kükürt dioksit, $\mathrm{d}_{15}{ }^{\max }=0,1 \mathrm{ppm}, \mathrm{t}(16)$ : ozon, $\mathrm{d}_{16}{ }^{\max }=0,1 \mathrm{ppm}$

İş yeri ortamında zehir etkisi gösteren gaz olarak olarak; $\mathrm{t}(17)$ : Arsin, $\mathrm{d}_{17}{ }^{\max }=0,05 \mathrm{ppm}$

$\mathrm{t}$ (18) : fosfin, $\mathrm{d}_{18}{ }^{\max }=0,3 \mathrm{ppm}, \mathrm{t}$ (19) : stibin, $\mathrm{d}_{19}{ }^{\max }=0,1 \mathrm{ppm}$ t (20) : yüksek basınç, t (22) : kimyasal maddeler, t (23) : gürültü, t (24) : el-kol titreşimi,

t (25): tüm vücut titreşimi, t (26) : aydınlatma, $\mathrm{t}(27)$ : zararlı 1şınlar ve radyasyon,

$\mathrm{t}$ (28) : elektromanyetik alanlar, t (29) : sicak veya soğuk iklim, t (30) : düzensiz ve kaygan yüzeyler, t (31) : araç ve makinelerin hareketi, t (32) : makine hareketi ve parçaları,

t (33) : tehlikeli yüzeyler, t (34) : sicak veya soğuk yüzeyler, $\mathrm{t}(35)$ : el aletleri, t (36) : elektrik tesisat ve ekipmanları, t (37) : yangin, t (38) : patlama, $\mathrm{t}(39)$ : kaldırma ve taşıma,

t (40): durus bozuklukları, t (41): biyolojik tehlikeler, t (42) : stres, şiddet, tacizler

olarak belirlenir. Tehlikenin ortaya çıkma olası ğı; İd=5 'tehlikenin günde ortaya çıkması'(üyelik derecesi $\ddot{\ddot{i}}_{\text {iнTiMAL }}=1,0$ )

$\dot{I} \mathrm{~d}=4$ 'tehlikenin haftada ortaya çıkması' (üyelik derecesi $\ddot{\ddot{I}}_{\text {iнTiMAL }}=0,8$ )

$\dot{I} \mathrm{~d}=3$ 'tehlikenin ayda ortaya çıkması' (üyelik derecesi $\ddot{\ddot{i H T i M A L}}_{\text {int }}=0,6$ )

$\dot{I} d=2$ 'tehlikenin üç ayda ortaya çıkması' (üyelik derecesi $\ddot{\ddot{I}}_{\text {iнTiMAL }}=0,4$ )

İd=1 'tehlikenin yılda ortaya çıkması' (üyelik derecesi $\ddot{\ddot{i}}_{\text {iнTiMAL }}=0,2$ )

$\dot{I} \mathrm{~d}=0$ 'tehlikenin hiç ortaya çıkmaması' (üyelik derecesi $\ddot{u ̈}_{\text {iHTIMAL }}=0,0$ )

ifade edilir. Şekil 3 de gösterildiği gibi skor matrisi belirlenir.

\begin{tabular}{|c|c|c|c|c|c|}
\hline OLASILIK & $\begin{array}{c}1 \\
\text { çok düşük }\end{array}$ & $\begin{array}{c}2 \\
\text { düş̧ük }\end{array}$ & $\begin{array}{c}3 \\
\text { orta }\end{array}$ & $\begin{array}{c}4 \\
\text { yüksek }\end{array}$ & $\begin{array}{c}\mathbf{5} \\
\text { ÇOK YÜKSEK }\end{array}$ \\
\hline $\begin{array}{c}1 \\
\text { ÇOK düşük }\end{array}$ & $\begin{array}{c}1 \\
\text { IHMAL } \\
\text { EDILEBILIR }\end{array}$ & $\begin{array}{c}2 \\
\text { IHMAL } \\
\text { EDILEBILIR }\end{array}$ & $\begin{array}{c}3 \\
\text { DÜşü̉K }\end{array}$ & $\begin{array}{c}4 \\
\text { DÜşüKK }\end{array}$ & $\begin{array}{c}5 \\
\text { DÜşüKK }\end{array}$ \\
\hline $\begin{array}{c}2 \\
\text { düşük }\end{array}$ & $\underset{\substack{2 \\
\text { IHMAL } \\
\text { EDILEBILIR }}}{2}$ & $\begin{array}{c}4 \\
\text { DÜșüKK }\end{array}$ & $\begin{array}{l}6 \\
\text { DÜșü̉K }\end{array}$ & $\begin{array}{c}8 \\
\text { ORTA }\end{array}$ & $\begin{array}{r}10 \\
\text { ORTA }\end{array}$ \\
\hline $\begin{array}{c}3 \\
\text { ORTA }\end{array}$ & $\stackrel{3}{3}$ Düşük & $\begin{array}{c}6 \\
\text { DÜșüK }\end{array}$ & $\begin{array}{c}9 \\
\text { ORTA }\end{array}$ & $\begin{array}{c}12 \\
\text { ORTA }\end{array}$ & $\begin{array}{c}15 \\
\text { YÜKSEKK }\end{array}$ \\
\hline $\begin{array}{c}4 \\
\text { YÜKSEK }\end{array}$ & $\begin{array}{c}4 \\
\text { Düşǘ }\end{array}$ & $\begin{array}{c}8 \\
\text { ORTA }\end{array}$ & $\begin{array}{c}12 \\
\text { ORTA }\end{array}$ & $\begin{array}{c}16 \\
\text { YÜKSEK }\end{array}$ & $\begin{array}{c}20 \\
\text { YÜKSSEK }\end{array}$ \\
\hline $\begin{array}{c}\mathbf{5} \\
\text { ÇOK YÜKSEK }\end{array}$ & $\stackrel{5}{5}$ Düşük & $\begin{array}{c}10 \\
\text { ORTA }\end{array}$ & $\begin{array}{c}15 \\
\text { YÜKSEK }\end{array}$ & $\begin{array}{c}20 \\
\text { YÜKSEK }\end{array}$ & $\begin{array}{c}25 \\
\text { TOLERE } \\
\text { EDILEMEZ }\end{array}$ \\
\hline
\end{tabular}

Şekil 3. Skor matrisi 
Risk değerlendirme skoru ve üyelik derecesi; Risk $=$ şiddet $\mathrm{x}$ ihtimal

Skoru 25 olan riskler çok yüksek risktir ve üyelik derecesi $\ddot{u}_{\text {RisK }}=1,0$ dir.

Skoru 15 ile 25 arası olan riskler yüksek risktir ve üyelik derecesi $\ddot{u}_{\text {RisK }}=0,8$ dir.

Skoru 8 ile 12 arası olan riskler orta risktir ve üyelik derecesi $\ddot{u}_{\text {RisK }}=0,6$ dir.

Skoru 3 ile 6 arası olan riskler düşük risktir ve üyelik derecesi $\ddot{u}_{\text {RisK }}=0,4$ dir.

Skoru 1ve 2 olan riskler çok düşük risktir ve üyelik derecesi $\ddot{u}_{\mathrm{RiSK}}=0,2$ dir.

Skoru 0 olan ise risk yoktur ve üyelik derecesi $\ddot{\mathrm{u}}_{\mathrm{RisK}}=0,0 \mathrm{dir}$.

olarak tanımlanır. İlk olarak tanımlanmış tehlikelerin perunit değerleri $\mathrm{d}_{\mathrm{t}}{ }^{\mathrm{n}}=\mathrm{d}_{\mathrm{t}} / \mathrm{d}_{\mathrm{t}}{ }^{\max }, \mathrm{t}=1$, ..... o. olarak hesaplanır, daha sonra tanımlanmayan tehlikelerin perunit değerleri $\underline{\mathrm{d}}_{t}^{\mathrm{n}}=$ $\underline{\mathrm{d}}_{\underline{t}} / \underline{\mathrm{d}}_{\mathrm{t}}^{\max }, \mathrm{t}=\mathrm{T}^{\prime}+1, \ldots . \mathrm{T}$ olarak hesaplanır, her bir bulanık sayı skalası, $\underline{d}_{\underline{t}}^{\mathrm{n}}, \quad \mathrm{r}_{\mathrm{t}}, \quad \mathrm{t}=\mathrm{T}^{\prime}+1, \ldots \ldots, \mathrm{T}$ maksimum yöntem ile tanımlanır, her bir tanımlanmış tehlikenin bulanık tanımı her bir $\mathrm{t}=1$, .....T ${ }^{\prime}$ için $\underline{c}_{t}=\underline{W}_{t} \cdot \underline{d}_{t}{ }^{n}$ hesaplanır ve bütün dilbilimsel tehlikeler her bir $\mathrm{t}^{\prime} \mathrm{T}^{\prime}+1, \ldots . \mathrm{T}$ için $\mathrm{c}_{\mathrm{t}}=\underline{\mathrm{W}}_{\mathrm{t}} \cdot \mathrm{r}_{\mathrm{t}}$ hesaplanarak tehlikelerin sirası bulanık sayıların karşılaştırma yöntemiyle üzerine temellendirilir. Bulanıklık kümeleri tanımlandıktan ve onların üyelik fonksiyonlarını atadıktan sonra, kurallar kontrol değişkeninin her bir kombinasyonu için yazılır. Bu kurallar, karar vermede If-Then ifadelerini kullanarak, giriş değişkenleriyle çıkış değişkenleri arasında ilişki kurulur. If şartı her bir kuralın Then sonucuna giden bir önertidir. Genelde her bir kural If (önerti) Then (sonuç) Else tarzında gösterilir ve eş sonuç ifadeleri çıkarıldığında kombinasyonlu 1024 adet kural oluşturulmuştur. Yazılım Şekil 4'de gösterildiği gibi oluşturulmuştur.

If $\mathrm{t}(1)=\mathrm{Nd}$ and $\mathrm{t}(2)=\mathrm{Nd}$ and $\mathrm{t}(3)=\mathrm{Nd}$ and $\mathrm{t}(4)=\mathrm{Yd}$ and $\mathrm{t}(5)=\mathrm{Nd}$ and $\mathrm{t}(6)=\mathrm{Nd}$ and $\mathrm{t}(7)=$ $\mathrm{Nd}$ and $\mathrm{t}(8)=\mathrm{Nd}$ and $\mathrm{t}(9)=\mathrm{Nd}$ and $\mathrm{t}(10)=\mathrm{Nd}$ and $\mathrm{t}(11)=\mathrm{Nd}$ and $\mathrm{t}(12)=\mathrm{Nd}$ and $\mathrm{t}(13)=\mathrm{Nd}$ and $\mathrm{t}(14)=\mathrm{Nd}$ and $\mathrm{t}(15)=\mathrm{Nd}$ and $\mathrm{t}(16)=\mathrm{Nd}$ and $\mathrm{t}(17)=\mathrm{Nd}$ and $\mathrm{t}(18)=\mathrm{Nd}$ and $\mathrm{t}(19)=\mathrm{Nd}$ and $\mathrm{t}(20)=\mathrm{Nd}$ and $\mathrm{t}(21)=\mathrm{Nd}$ and $\mathrm{t}(22)=\mathrm{Nd}$ and $\mathrm{t}(23)=\mathrm{Nd}$ and $\mathrm{t}(24)=\mathrm{Nd}$ and $\mathrm{t}(25)=\mathrm{Nd}$ and $\mathrm{t}(26)=\mathrm{Nd}$ and $\mathrm{t}(27)=\mathrm{Nd}$ and $\mathrm{t}(28)=\mathrm{Nd}$ and $\mathrm{t}(29)=\mathrm{Nd}$ and $\mathrm{t}(30)=\mathrm{Nd}$ and $\mathrm{t}(31)=\mathrm{Nd}$ and $\mathrm{t}(32)=\mathrm{Nd}$ and $\mathrm{t}(33)=\mathrm{Nd}$ and $\mathrm{t}(34)=\mathrm{Nd}$ and $\mathrm{t}(35)=\mathrm{Nd}$ and $\mathrm{t}(36)=\mathrm{Nd}$ and $\mathrm{t}(37)=\mathrm{Nd}$ and $\mathrm{t}(38)=\mathrm{Nd}$ and $\mathrm{t}(39)=\mathrm{Nd}$ and $\mathrm{t}(40)=\mathrm{Nd}$ and $t(41)=\mathrm{Nd}$ and $\mathrm{t}(42)=\mathrm{Nd}$ then RISK $=\mathrm{COK}$ YUKSEK else

$>$ If $\mathrm{t}(1)=\mathrm{Nd}$ and $\mathrm{t}(2)=\mathrm{Nd}$ and $\mathrm{t}(3)=\mathrm{Nd}$ and $\mathrm{t}(4)=\mathrm{Nd}$ and $\mathrm{t}(5)=\mathrm{Yd}$ and $\mathrm{t}(6)=\mathrm{Nd}$ and $\mathrm{t}(7)=$ $\mathrm{Nd}$ and $\mathrm{t}(8)=\mathrm{Nd}$ and $\mathrm{t}(9)=\mathrm{Nd}$ and $\mathrm{t}(10)=\mathrm{Nd}$ and $\mathrm{t}(11)=\mathrm{Nd}$ and $\mathrm{t}(12)=\mathrm{Nd}$ and $\mathrm{t}(13)=\mathrm{Nd}$ and $\mathrm{t}(14)=\mathrm{Nd}$ and $\mathrm{t}(15)=\mathrm{Nd}$ and $\mathrm{t}(16)=\mathrm{Nd}$ and $\mathrm{t}(17)=\mathrm{Nd}$ and $\mathrm{t}(18)=\mathrm{Nd}$ and $\mathrm{t}(19)=\mathrm{Nd}$ and $t(20)=\mathrm{Nd}$ and $\mathrm{t}(21)=\mathrm{Nd}$ and $\mathrm{t}(22)=\mathrm{Nd}$ and $\mathrm{t}(23)=\mathrm{Nd}$ and $\mathrm{t}(24)=\mathrm{Nd}$ and $\mathrm{t}(25)=\mathrm{Nd}$ and $\mathrm{t}(26)=\mathrm{Nd}$ and $\mathrm{t}(27)=\mathrm{Nd}$ and $\mathrm{t}(28)=\mathrm{Nd}$ and $\mathrm{t}(29)=\mathrm{Nd}$ and $\mathrm{t}(30)=\mathrm{Nd}$ and $\mathrm{t}(31)=\mathrm{Nd}$ and $t(32)=\mathrm{Nd}$ and $\mathrm{t}(33)=\mathrm{Nd}$ and $\mathrm{t}(34)=\mathrm{Nd}$ and $\mathrm{t}(35)=\mathrm{Nd}$ and $\mathrm{t}(36)=\mathrm{Nd}$ and $\mathrm{t}(37)=\mathrm{Nd}$ and $\mathrm{t}(38)=\mathrm{Nd}$ and $\mathrm{t}(39)=\mathrm{Nd}$ and $\mathrm{t}(40)=\mathrm{Nd}$ and $\mathrm{t}(41)=\mathrm{Nd}$ and $\mathrm{t}(42)=\mathrm{Nd}$ then $\mathrm{RISK}=\mathrm{COK}$ YUKSEK else

If $\mathrm{t}(1)=\mathrm{Nd}$ and $\mathrm{t}(2)=\mathrm{Nd}$ and $\mathrm{t}(3)=\mathrm{Nd}$ and $\mathrm{t}(4)=\mathrm{Nd}$ and $\mathrm{t}(5)=\mathrm{Nd}$ and $\mathrm{t}(6)=\mathrm{Yd}$ and $\mathrm{t}(7)=$ $\mathrm{Nd}$ and $\mathrm{t}(8)=\mathrm{Nd}$ and $\mathrm{t}(9)=\mathrm{Nd}$ and $\mathrm{t}(10)=\mathrm{Nd}$ and $\mathrm{t}(11)=\mathrm{Nd}$ and $\mathrm{t}(12)=\mathrm{Nd}$ and $\mathrm{t}(13)=\mathrm{Nd}$ and $\mathrm{t}(14)=\mathrm{Nd}$ and $\mathrm{t}(15)=\mathrm{Nd}$ and $\mathrm{t}(16)=\mathrm{Nd}$ and $\mathrm{t}(17)=\mathrm{Nd}$ and $\mathrm{t}(18)=\mathrm{Nd}$ and $\mathrm{t}(19)=\mathrm{Nd}$ and $\mathrm{t}(20)=\mathrm{Nd}$ and $\mathrm{t}(21)=\mathrm{Nd}$ and $\mathrm{t}(22)=\mathrm{Nd}$ and $\mathrm{t}(23)=$

$\mathrm{Nd}$ and $\mathrm{t}(24)=\mathrm{Nd}$ and $\mathrm{t}(25)=\mathrm{Nd}$ and $\mathrm{t}(26)=\mathrm{Nd}$ and $\mathrm{t}(27)=\mathrm{Nd}$ and $\mathrm{t}(28)=\mathrm{Nd}$ and $\mathrm{t}(29)=\mathrm{Nd}$ and $\mathrm{t}(30)=\mathrm{Nd}$ and $\mathrm{t}(31)=\mathrm{Nd}$ and $\mathrm{t}(32)=\mathrm{Nd}$ and $\mathrm{t}(33)=\mathrm{Nd}$ and $\mathrm{t}(34)=\mathrm{Nd}$ and $\mathrm{t}(35)=\mathrm{Nd}$ and $\mathrm{t}(36)=\mathrm{Nd}$ and $\mathrm{t}(37)=\mathrm{Nd}$ and $\mathrm{t}(38)=\mathrm{Nd}$ and $\mathrm{t}(39)=\mathrm{Nd}$ and $\mathrm{t}(40)=\mathrm{Nd}$ and $\mathrm{t}(41)=\mathrm{Nd}$ and $\mathrm{t}(42)=\mathrm{Nd}$ then RISK=COK YUKSEK else

If $\mathrm{t}(1)=\mathrm{Nd}$ and $\mathrm{t}(2)=\mathrm{Nd}$ and $\mathrm{t}(3)=\mathrm{Nd}$ and $\mathrm{t}(4)=\mathrm{Nd}$ and $\mathrm{t}(5)=\mathrm{Nd}$ and $\mathrm{t}(6)=\mathrm{Nd}$ and $\mathrm{t}(7)=$ $\mathrm{Yd}$ and $\mathrm{t}(8)=\mathrm{Nd}$ and $\mathrm{t}(9)=\mathrm{Nd}$ and $\mathrm{t}(10)=\mathrm{Nd}$ and $\mathrm{t}(11)=\mathrm{Nd}$ and $\mathrm{t}(12)=\mathrm{Nd}$ and $\mathrm{t}(13)=\mathrm{Nd}$ and $\mathrm{t}(14)=\mathrm{Nd}$ and $\mathrm{t}(15)=\mathrm{Nd}$ and $\mathrm{t}(16)=\mathrm{Nd}$ and $t(17)=\mathrm{Nd}$ and $\mathrm{t}(18)=\mathrm{Nd}$ and $\mathrm{t}(19)=\mathrm{Nd}$ and $t(20)=N d$ and $t(21)=N d$ and $t(22)=N d$ and $\mathrm{t}(23)=\mathrm{Nd}$ and $\mathrm{t}(24)=\mathrm{Nd}$ and $\mathrm{t}(25)=\mathrm{Nd}$ and $\mathrm{t}(26)=\mathrm{Nd}$ and $\mathrm{t}(27)=\mathrm{Nd}$ and $\mathrm{t}(28)=\mathrm{Nd}$ and $\mathrm{t}(29)=\mathrm{Nd}$ and $\mathrm{t}(30)=\mathrm{Nd}$ and $\mathrm{t}(31)=\mathrm{Nd}$ and $\mathrm{t}(32)=\mathrm{Nd}$ and $\mathrm{t}(33)=\mathrm{Nd}$ and $\mathrm{t}(34)=\mathrm{Nd}$ and $\mathrm{t}(35)=\mathrm{Nd}$ and $\mathrm{t}(36)=\mathrm{Nd}$ and $\mathrm{t}(37)=\mathrm{Nd}$ and $\mathrm{t}(38)=\mathrm{Nd}$ and $\mathrm{t}(39)=\mathrm{Nd}$ and $\mathrm{t}(40)=\mathrm{Nd}$ and $\mathrm{t}(41)=\mathrm{Nd}$ and $\mathrm{t}(42)=\mathrm{Nd}$ then $\mathrm{RISK}=\mathrm{COK}$ 
YUKSEK else

If $\mathrm{t}(1)=\mathrm{Nd}$ and $\mathrm{t}(2)=\mathrm{Nd}$ and $\mathrm{t}(3)=\mathrm{Nd}$ and $\mathrm{t}(4)=\mathrm{Nd}$ and $\mathrm{t}(5)=\mathrm{Nd}$ and $\mathrm{t}(6)=\mathrm{Nd}$ and $\mathrm{t}(7)=$ $\mathrm{Nd}$ and $\mathrm{t}(8)=\mathrm{Yd}$ and $\mathrm{t}(9)=\mathrm{Nd}$ and $\mathrm{t}(10)=\mathrm{Nd}$ and $\mathrm{t}(11)=\mathrm{Nd}$ and $\mathrm{t}(12)=\mathrm{Nd}$ and $\mathrm{t}(13)=\mathrm{Nd}$ and $\mathrm{t}(14)=\mathrm{Nd}$ and $\mathrm{t}(15)=\mathrm{Nd}$ and $\mathrm{t}(16)=\mathrm{Nd}$ and $\mathrm{t}(17)=\mathrm{Nd}$ and $\mathrm{t}(18)=\mathrm{Nd}$ and $\mathrm{t}(19)=\mathrm{Nd}$ and $\mathrm{t}(20)=\mathrm{Nd}$ and $\mathrm{t}(21)=\mathrm{Nd}$ and $\mathrm{t}(22)=\mathrm{Nd}$ and $\mathrm{t}(23)=\mathrm{Nd}$ and $\mathrm{t}(24)=\mathrm{Nd}$ and $\mathrm{t}(25)=\mathrm{Nd}$ and $\mathrm{t}(26)=\mathrm{Nd}$ and $\mathrm{t}(27)=\mathrm{Nd}$ and $\mathrm{t}(28)=\mathrm{Nd}$ and $\mathrm{t}(29)=\mathrm{Nd}$ and $\mathrm{t}(30)=\mathrm{Nd}$ and $\mathrm{t}(31)=\mathrm{Nd}$ and $\mathrm{t}(32)=\mathrm{Nd}$ and $\mathrm{t}(33)=\mathrm{Nd}$ and $\mathrm{t}(34)=\mathrm{Nd}$ and $\mathrm{t}(35)=\mathrm{Nd}$ and $\mathrm{t}(36)=\mathrm{Nd}$ and $\mathrm{t}(37)=\mathrm{Nd}$ and $\mathrm{t}(38)=\mathrm{Nd}$ and $\mathrm{t}(39)=\mathrm{Nd}$ and $\mathrm{t}(40)=\mathrm{Nd}$ and $\mathrm{t}(41)=\mathrm{Nd}$ and $\mathrm{t}(42)=\mathrm{Nd}$ then $\mathrm{RISK}=\mathrm{COK}$ YUKSEK else

If $\mathrm{t}(1)=\mathrm{Nd}$ and $\mathrm{t}(2)=\mathrm{Nd}$ and $\mathrm{t}(3)=\mathrm{Nd}$ and $\mathrm{t}(4)=\mathrm{Nd}$ and $\mathrm{t}(5)=\mathrm{Nd}$ and $\mathrm{t}(6)=\mathrm{Nd}$ and $\mathrm{t}(7)=$ $\mathrm{Nd}$ and $\mathrm{t}(8)=\mathrm{Nd}$ and $\mathrm{t}(9)=\mathrm{Yd}$ and $\mathrm{t}(10)=\mathrm{Nd}$ and $t(11)=N d$ and $t(12)=N d$ and $t(13)=N d$ and $\mathrm{t}(14)=\mathrm{Nd}$ and $\mathrm{t}(15)=\mathrm{Nd}$ and $\mathrm{t}(16)=\mathrm{Nd}$ and $\mathrm{t}(17)=\mathrm{Nd}$ and $\mathrm{t}(18)=\mathrm{Nd}$ and $\mathrm{t}(19)=\mathrm{Nd}$ and $\mathrm{t}(20)=\mathrm{Nd}$ and $\mathrm{t}(21)=\mathrm{Nd}$ and $\mathrm{t}(22)=\mathrm{Nd}$ and $\mathrm{t}(23)=\mathrm{Nd}$ and $\mathrm{t}(24)=\mathrm{Nd}$ and $\mathrm{t}(25)=\mathrm{Nd}$ and $\mathrm{t}(26)=\mathrm{Nd}$ and $\mathrm{t}(27)=\mathrm{Nd}$ and $\mathrm{t}(28)=\mathrm{Nd}$ and $\mathrm{t}(29)=\mathrm{Nd}$ and $\mathrm{t}(30)=\mathrm{Nd}$ and $\mathrm{t}(31)=\mathrm{Nd}$ and $\mathrm{t}(32)=\mathrm{Nd}$ and $\mathrm{t}(33)=\mathrm{Nd}$ and $\mathrm{t}(34)=\mathrm{Nd}$ and $\mathrm{t}(35)=\mathrm{Nd}$ and $\mathrm{t}(36)=\mathrm{Nd}$ and $\mathrm{t}(37)=\mathrm{Nd}$ and $\mathrm{t}(38)=\mathrm{Nd}$ and $\mathrm{t}(39)=\mathrm{Nd}$ and $\mathrm{t}(40)=\mathrm{Nd}$ and $\mathrm{t}(41)=\mathrm{Nd}$ and $\mathrm{t}(42)=\mathrm{Nd}$ then $\mathrm{RISK}=\mathrm{COK}$ YUKSEK else

$>$ If $\mathrm{t}(1)=\mathrm{Nd}$ and $\mathrm{t}(2)=\mathrm{Nd}$ and $\mathrm{t}(3)=\mathrm{Nd}$ and $\mathrm{t}(4)=\mathrm{Nd}$ and $\mathrm{t}(5)=\mathrm{Nd}$ and $\mathrm{t}(6)=\mathrm{Nd}$ and $\mathrm{t}(7)=$ $\mathrm{Nd}$ and $\mathrm{t}(8)=\mathrm{Nd}$ and $\mathrm{t}(9)=\mathrm{Nd}$ and $\mathrm{t}(10)=\mathrm{Yd}$ and $\mathrm{t}(11)=\mathrm{Nd}$ and $\mathrm{t}(12)=\mathrm{Nd}$ and $\mathrm{t}(13)=\mathrm{Nd}$ and $\mathrm{t}(14)=\mathrm{Nd}$ and $\mathrm{t}(15)=\mathrm{Nd}$ and $\mathrm{t}(16)=\mathrm{Nd}$ and $\mathrm{t}(17)=\mathrm{Nd}$ and $\mathrm{t}(18)=\mathrm{Nd}$ and $\mathrm{t}(19)=\mathrm{Nd}$ and $\mathrm{t}(20)=\mathrm{Nd}$ and $\mathrm{t}(21)=\mathrm{Nd}$ and $\mathrm{t}(22)=\mathrm{Nd}$ and $\mathrm{t}(23)=\mathrm{Nd}$ and $\mathrm{t}(24)=\mathrm{Nd}$ and $\mathrm{t}(25)=\mathrm{Nd}$ and $\mathrm{t}(26)=\mathrm{Nd}$ and $\mathrm{t}(27)=\mathrm{Nd}$ and $\mathrm{t}(28)=\mathrm{Nd}$ and $\mathrm{t}(29)=\mathrm{Nd}$ and $\mathrm{t}(30)=\mathrm{Nd}$ and $\mathrm{t}(31)=\mathrm{Nd}$ and $\mathrm{t}(32)=\mathrm{Nd}$ and $\mathrm{t}(33)=\mathrm{Nd}$ and $\mathrm{t}(34)=\mathrm{Nd}$ and $\mathrm{t}(35)=\mathrm{Nd}$ and $\mathrm{t}(36)=\mathrm{Nd}$ and $\mathrm{t}(37)=\mathrm{Nd}$ and $\mathrm{t}(38)=\mathrm{Nd}$ and $\mathrm{t}(39)=\mathrm{Nd}$ and $\mathrm{t}(40)=\mathrm{Nd}$ and $\mathrm{t}(41)=\mathrm{Nd}$ and $\mathrm{t}(42)=\mathrm{Nd}$ then $\mathrm{RISK}=\mathrm{COK}$ YUKSEK else

$>$ If $\mathrm{t}(1)=\mathrm{Nd}$ and $\mathrm{t}(2)=\mathrm{Nd}$ and $\mathrm{t}(3)=\mathrm{Nd}$ and $\mathrm{t}(4)=\mathrm{Nd}$ and $\mathrm{t}(5)=\mathrm{Nd}$ and $\mathrm{t}(6)=\mathrm{Nd}$ and $\mathrm{t}(7)=$ $\mathrm{Nd}$ and $\mathrm{t}(8)=\mathrm{Nd}$ and $\mathrm{t}(9)=\mathrm{Nd}$ and $\mathrm{t}(10)=\mathrm{Nd}$ and $\mathrm{t}(11)=\mathrm{Yd}$ and $\mathrm{t}(12)=\mathrm{Nd}$ and $\mathrm{t}(13)=\mathrm{Nd}$ and $\mathrm{t}(14)=\mathrm{Nd}$ and $\mathrm{t}(15)=\mathrm{Nd}$ and $\mathrm{t}(16)=\mathrm{Nd}$ and $\mathrm{t}(17)=\mathrm{Nd}$ and $\mathrm{t}(18)=\mathrm{Nd}$ and $\mathrm{t}(19)=\mathrm{Nd}$ and $\mathrm{t}(20)=\mathrm{Nd}$ and $\mathrm{t}(21)=\mathrm{Nd}$ and $\mathrm{t}(22)=\mathrm{Nd}$ and $\mathrm{t}(23)=\mathrm{Nd}$ and $\mathrm{t}(24)=\mathrm{Nd}$ and $\mathrm{t}(25)=\mathrm{Nd}$ and $\mathrm{t}(26)=\mathrm{Nd}$ and $\mathrm{t}(27)=\mathrm{Nd}$ and $\mathrm{t}(28)=\mathrm{Nd}$ and $\mathrm{t}(29)=\mathrm{Nd}$ and $\mathrm{t}(30)=\mathrm{Nd}$ and $\mathrm{t}(31)=\mathrm{Nd}$ and $\mathrm{t}(32)=\mathrm{Nd}$ and $\mathrm{t}(33)=\mathrm{Nd}$ and $\mathrm{t}(34)=\mathrm{Nd}$ and $\mathrm{t}(35)=\mathrm{Nd}$ and $\mathrm{t}(36)=\mathrm{Nd}$ and $\mathrm{t}(37)=\mathrm{Nd}$ and $\mathrm{t}(38)=\mathrm{Nd}$ and $\mathrm{t}(39)=\mathrm{Nd}$ and $\mathrm{t}(40)=\mathrm{Nd}$ and $\mathrm{t}(41)=\mathrm{Nd}$ and $\mathrm{t}(42)=\mathrm{Nd}$ then $\mathrm{RISK}=\mathrm{COK}$ YUKSEK else

Şekil 4. Yazılım

Riskler kümesi Şekil 5' de gösterildiği gibi elde edilir.

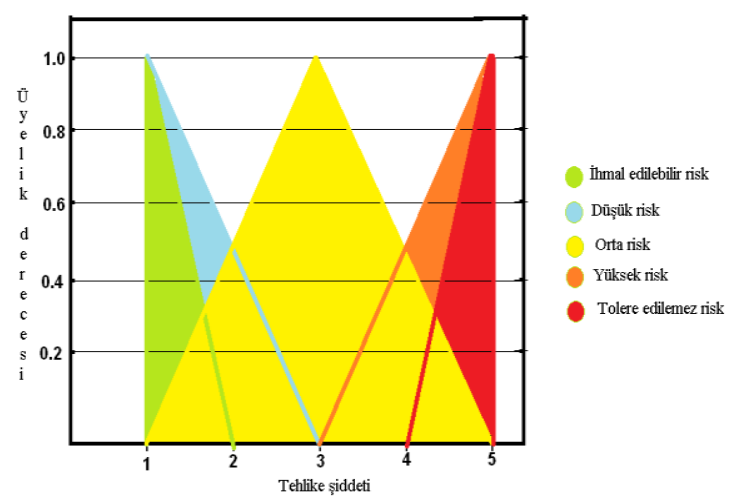

Şekil 5. Riskler kümesi

Şekil 5'de görüldüğü gibi, $\mathrm{F}_{1}=(\mathrm{x} ; 1,1,2)$ üçgen bulanık kümesi ihmal edilebilir riskleri, $\mathrm{F}_{2}=(\mathrm{x} ; 2,1,3)$ üçgen bulanık kümesi düşük riskleri, $\mathrm{F}_{3}=(\mathrm{x} ; 1,3,5)$ üçgen bulanık kümesi orta riskleri, $\mathrm{F}_{4}=(\mathrm{x} ; 3,5,4)$ üçgen bulanık kümesi yüksek riskleri ve $\mathrm{F}_{5}=(\mathrm{x} ; 4,5,5)$ üçgen bulanık kümesi ise tolere edilmez yüksek riskleri göstermektedir.

\section{SONUÇLAR ve ÖNERILER}

Risk değerlendirme ve analizi ile işyerinde bulunan veya dişarıdan gelebilecek tehlikelerin tanımlanması, bu tehlikelerin riske dönüşmesine yol açan faktörler ile tehlikelerden kaynaklanan 
risklerin analiz edilerek derecelendirilmesi ve kontrol tedbirlerinin kararlaştırılması mümkündür. İş yerlerindeki riskler yapılan işlerden, yürütülen işlemler ve çeşitli yöntemlerden, kullanılan maddelerden, her türlü makine ve donanımlardan, iş yeri veya çevresinde bulunan çalışanlardan, iş yerinde oluşturulan organizasyonlardan çevre koşullarından ve çeşitli unsurların birbirleri ile etkileşmesinden kaynaklanır. Birçok belirli ve belirsiz tehlikeler olan işyeri ortamında risk değerlendirmesini ve bu tehlikeleri simule etmek için bir sistem modellemesi yapmak çok zordur. Birçok belirli ve belirsiz tehlikeler olan işyeri ortamında risk değerlendirmesini ve bu tehlikeleri simule etmek için bir sistem modellemesi yapmak çok zordur. $\mathrm{Bu}$ çalışmada iş sağlı̆̆ ve güvenliğinde bir çok tehlikeyi göz önüne alarak bulanık mantık temelli bir risk değerlendirme analiz modeli oluşturularak bir bilgisayar yazılımı geliştirilmiştir.

\section{KAYNAKLAR}

1. Zile, M., 2013. Adliyeye İntikal Eden İş Kazaların Analizi ve Nedensellik Modellemesinin Oluşturulması, VII.Ulusal İşçi Sağlığı ve İş Güvenliği Kongresi, Yayın No:E/2013/600, 295-298, Çukurova Üniversitesi Adana.

2. Zile, M., 2013. Elektrik Enerjisi Kaynaklı Adli Vaka İş Kazalarında Sebeplendirme Yaklaşımları ve İş Güvenliğinin Oluşturulması VII.Ulusal İşçi Sağlığı ve İş Güvenliği Kongresi, Yayın No:E/2013/600, 295-300, Çukurova Üniversitesi, Adana.

3. Zile, M., 2015. Elektronik Algılayıcılar İle Olası İş Kazalarının Önlenmesi’ VIII.Ulusal İşçi Sağlığı ve İş Güvenliği Kongresi, Yayın No:E/2015/635, 425-430, Çukurova Üniversitesi, Adana.

4. Zile, M., 2015. Bakım Ve Onarım Kaynaklı Adli Vaka İş Kazalarında Sebeplendirme Yaklaşımları Ve Alınması Gereken Önlemler' VIII.Ulusal İşçi Sağlığı ve İş Güvenliği Kongresi, Yayın No:E/2015/635, 625-626, Çukurova Üniversitesi, Adana.
5. Zile, M., 2015. Bakım Bulanık Mantık Temelli Oluşturulan İş Güvenliği Risk Değerlendirme Analiz Modellemesi ve Yazılımı, Endüstriyel Otomasyon Kongre ve Sergisi, Yayın No:E/MMO/642, 209-215, Çukurova Üniversitesi, Adana.

6. 6331 Sayılı İş Kanunu

7. İş Sağlığ1 ve Güvenliği Yönetmeliği

8. İşçi Sağlığı ve İş Güvenliği Tüzüğü 
